v. 7, n.2

Vitória-ES, May - Aug . 2010

p.60- $77 \quad$ ISSN $1808-2386$

DOI: http://dx.doi.org/10.15728/bbr.2010.7.2.4

\title{
The influence of store image on customer satisfaction: a case study of a shoe
} store

\author{
Tarsis Souza Silva ${ }^{\dagger}$ \\ University of São Paulo - USP \\ Janaina de Moura Engracia Giraldi ${ }^{\Omega}$ \\ University of São Paulo -USP
}

\begin{abstract}
Knowledge of customers' image of a store is an essential factor in the management of retail outlets. This article presents a case study of the effect of the image customers have of a shoe store on their satisfaction, based on a descriptive and quantitative survey, with the application of a structured questionnaire. We then employed factor analysis to obtain seven store image factors: assortment, convenience, reputation, price, atmosphere, layout and service. The results show that the factor that most affects customer satisfaction in the store studied is service, and that atmosphere and layout have no effect in this respect. The results provide a better understanding of the role store image plays in customer satisfaction and loyalty.
\end{abstract}

Key words: Store image, retailing, customer satisfaction, shoe sector.

Received in 04/28/2010; revised in 05/02/2010; accept in 05/29/2010.

Corresponding authors*:

† Bachelor's in Business Administration from University of São Paulo.

Institution: University of São Paulo.

$\Omega^{\Omega}$ Doctorate in Business Administration from University of São Paulo Institution: University of São Paulo

Address: Avenida dos Bandeirantes, 3900, FEA-RP, Bloco

Address: Praça Santa Paula Frassinetti, 172, Lagoinha, São

Sebastião do Paraíso - MG - Brazil, 37950-000.

A. Ribeirão Preto - SP - Brazil - CEP: 14040-905.

E-mail: tarsis.s.silva@gmail.com

E-mail: jgiraldi@usp.br

Telephone: (35) 3531-3682

Telephone: (16) 3602-3903

Fax: (35) 3531-3682

Fax: (16) 3602-3903

Editor's note: This paper was accepted by Antonio Lopo Martinez 


\section{INTRODUCTION}

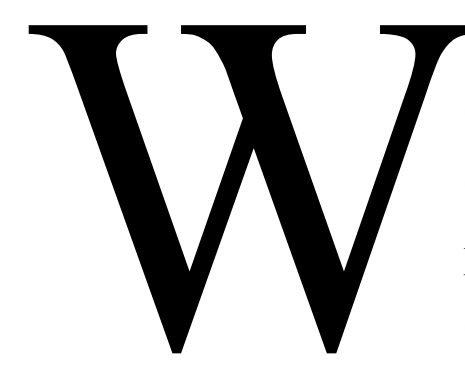

th the growth and modernization of the retail sector, the pace of change of sales models has also picked up. Retailers have to keep close tabs on the image of their stores in customers' eyes to remain profitable. The retail sector in Brazil is overwhelmingly composed of companies with fewer than 20 employees: $97.8 \%$ of enterprises fall into this category, representing $29.4 \%$ of the sector's sales revenue (IBGE, 2005). According to official statistics, in 2006 the retail sector employed 7,599,505 people, and stores with up to 19 employees employed 4,826,855, accounting for $60 \%$ of the total number of employees (IBGE, 2006). These figures show the importance of small businesses in the Brazilian retail sector and the scope for expansion and greater professionalism that exists, since revenue is not proportional to the number of people employed by firms.

In light of this scenario, there is significant room for development of retail management models, including the application of techniques to detect customers' image of stores, as a key tool to maintain and expand business. According to Bloemer \& Ruyter (1998), store image is a set of perceptions held by consumers of a store's various attributes. The most important attributes are evaluated and weighted against each other and the result portrays consumers' image of the store. For Kunkel \& Berry (1968), image can be defined as the discriminative stimuli for an action's expected reinforcement. Therefore, the store image is the result of different past reinforcements in the context of the store being analyzed. It is evident that an important facet of a store's image is the previous experience of its customers. Rewarding past experiences lead to a favorable store image while negative experiences have the opposite effect (Kunkel \& Berry, 1968).

Another important concept for the retail sector is customer satisfaction with the store. For Sheth, Mitall \& Newman (2001) and Hunt (1991), customer satisfaction or dissatisfaction entails a comparison of customers' expectations against their perceptions of the product, service or store, that is, a comparison of the real against the expected performance.In the present article we study the concepts of customer image and satisfaction in the footwear sector in Brazil.

According to the Brazilian Association of Footwear Industries (Associação Brasileira das Indústrias de Calçados, 2008), the Brazilian footwear sector produced around 808 million 
pairs of shoes in 2007, by 7,830 firms. Most of this output (around 660 million pairs) was consumed in the domestic market. Santos \& Dias (2008) reported that over the past five years the Brazilian retail sector experienced substantial changes in commercial and marketing conditions, altering the competitive bases of the footwear segment in the country. The main element of this change was consumer behavior, with customers increasingly conscious of style, particularly whether a particular shoe model goes well with other clothes, as well as adequacy for the conditions of use. This new trend has left the traditional vision of shoes as only a basic wardrobe item by the wayside.In this context, this article studies the influence of customer image of a shoe store on their satisfaction, based on a survey among the store's customers to discover which dimensions of their image of the store have the most influence on their level of satisfaction. In the next section we discuss the concepts of store image and the ways of measuring it. Then we present the concept of satisfaction and its relationship with store image. After that we present the methodological aspects, before analyzing the results and conclusions.

\section{STORE IMAGE}

According to Martineau (1958), retail stores have a personality and should be able to create empathy with their customers. This personality, or store image, is formed based on functional characteristics and psychological attributes. He conducted a survey which indicated that the reasons consumers give preference to a particular store mainly involve the intrinsic aspects of the store that are less tangible and were not generally taken into consideration at the time his article was published. McGoldrick (1990) criticized the definition of image of Martineau (1958) for attributing a mystical aspect to the concept. According to this critique, the assumption that consumers evaluate a store by its intrinsic aspects indirectly affirms they do not act rationally. Other authors have suggested that instead of defining image as part of consumer behavior without a logical basis, it is more reasonable to assume that consumers evaluate a store rationally, through a multi-attribute utility function.

Among these authors are Bloemer \& Schroder (2002). According to them, a store's image is the sum of all its attributes, based on consumers' perceptions of their experiences with the store. Sheth, Mittal \& Newman (2001) also defined store image according to this multi-attribute concept: the store's image is the sum of all the perceptions its patrons have about it. These perceptions are determined based on factors such as products, price, service and atmosphere. James, Durand \& Dreves (1976) defined store image as being a set of 
attitudes based on the evaluation of the store's attributes that are considered important by customers. Since attitudes are formed through a learning process, the store's image depends on the customers' experiences with it. These experiences are not always directly related with the store, although buying from a store is obviously one way to gain experience. However, talking to friends about their experiences at the store and looking at window displays also bring experience to consumers. Kunkel \& Berry (1968) followed the same line of thinking of James, Durand \& Dreves (1976), according to which customers' personal experience is an important aspect of a store's image. Because this image is acquired by experience, it is learned. When a need to purchase something arises, the typical consumer will carry out some investigations and, when entering the target store, will only have uncertain expectations.

This shopper will then be rewarded, punished or both when buying the needed item, depending on his or her state variables, societal and sub-cultural norms and also buying experiences there. Blacwell, Miniard \& Engel (2005) examined another aspect of store image and stated that each store apparently has a set of associations and other information that are stored in shoppers' memories. The full set of these associations defines both the image of a given store. These associations can involve the outward characteristics of a store as well as the benefits and feelings that come from buying from it. They can also include symbols, people, advertising campaigns, slogans and logos, among others. According to Hawkins, Mothersbaugh \& Best (2007), store image refers to customers' schematic memory. This memory contains the interpretation about the attributes, benefits and characteristics of the store. It is what people feel and think when buying from a certain store or hearing comments about it. Thus, it is the set of associations that consumers learn about a store.

According to the authors, store image is one of the criteria used by consumers in choosing a store. Keaveney (1992) stated that in planning and evaluating their store image, retailers should consider that, from the typical consumer's point of view image is a set of related characteristics. Consumers in general do not mentally measure the aisles, do not evaluate the type of shelves used and do not observe the color scheme, to name a few of the many store attributes. On the contrary, they form general impressions about the store and compare them with those of other stores. In the next section we present a summary of the components of store image and discuss the ways of measuring this concept.

\section{COMPONENTS OF STORE IMAGE AND WAYS OF MEASURING THEM}

We conducted a comprehensive review of the literature on the components and subcomponents of store image. Chart 1 consolidates the results. According to Birtwistle, BBR, Braz. Bus. Rev. (Engl. ed., Online),

www.bbronline.com.br 
Clarke \& Freathy (1999), the most common technique used to measure store image is to ask shoppers to evaluate the target store according to a predefined scale. Semantic differential, Likert and Stapel scales are some of those employed to measure store image (Birtwistle; Clarke \& Freathy, 1999; Menezes \& Elbert, 1979). The semantic differential scale is a sevenpoint scale in which the extreme points are adjectives that represent opposites. On a Likert scale, respondents are asked to indicate their level of agreement among five response categories (though some variations use seven or nine categories). The extreme points on this scale are "strongly disagree" and "strongly agree". A Stapel scale is usually presented vertically with an adjective at the middle point on a scale ranging from +5 to -5 . There is no 0 point, thus not allowing a neutral response. The respondent chooses a number to indicate how precise or imprecise each term is in describing the object of study. The greater the positive response, the more accurately the respondent believes the term describes the object, and the more negative it is, the less accurate the description is (Malhotra, 2001).

\begin{tabular}{|c|c|}
\hline Components & Subcomponents \\
\hline Product Price & $\begin{array}{c}\text { Low prices, competitive or satisfactory prices, uncompetitive or high } \\
\text { prices }\end{array}$ \\
\hline Product Quality & Good or bad quality and in-stock brands \\
\hline Clientele & Characteristics of the customers that shop at the store \\
\hline Assortment & Range, depth, sells brands that attract customers \\
\hline Physical Premises & Cleanliness, layout, ease of buying and attractiveness \\
\hline Product Style & Keeping up with the latest styles \\
\hline Sales Staff & $\begin{array}{l}\text { Attitude of the sale staff, knowledge of the sales staff, number of } \\
\text { salespersons, good or bad service, friendliness }\end{array}$ \\
\hline Location Convenience & Location near home or work, access, good or bad location \\
\hline Other Items & Parking, open hours, general convenience, layout \\
\hline Services & Credit, lay-away plan, delivery and other services \\
\hline Sales Promotions & Special sales, coupons, special events \\
\hline Advertising & Quality and style of advertising, media used, credibility of advertising \\
\hline Store Atmosphere & $\begin{array}{l}\text { Layout, lighting, temperature, visual communication, colors, size of sales } \\
\text { area, outside and inside decoration, product display, crowding within the } \\
\text { store, prestige }\end{array}$ \\
\hline Policy on Refunds and Exchanges & Policy on refunds and exchanges \\
\hline Institutional Aspects & Store reputation \\
\hline After-sales & Level of satisfaction \\
\hline
\end{tabular}

\section{CHART 1 - COMPONENTS OF STORE IMAGE}

Source: Adapted from Kunkel \& Berry (1968), Lindquist (1974), James, Durand \& Dreves (1976), Parente (2000), Doyle \& Fenwick (1974), Bearden (1977), Birtwistle, Clarke \& Freathy (1999), Ghosh (1990) and Hirshman, Greenberg \& Robertson (1978). 
Kunkel \& Berry (1968) also examined methods to measure store image and stressed they are non-structured. Reardon, Miller \& Coe (1995) investigated the same theme. In nonstructured questionnaires with open-ended questions, the respondent is only free to discuss what is relevant in the store image. In other words, only important components of the retailer are cited, unlike in a semantic differential study, which requires responses to all the components on the questionnaire, and for this reason does not serve to isolate important components of the image.

Menezes \& Elbert (1979) compared the differences of the Likert, semantic differential and Stapel scales and reached some conclusions about the advantages of each scale. For example, the semantic differential scale appears to be more precise, because the variability among the respondents is reduced. But since they found there are no general differences among the three scales, they stressed another important point to consider in choosing the scale: know the profile of the sample population, to allow adapting the questions to facilitate comprehension.

Birtwistle, Clarke \& Freathy (1999) pointed out two problems encountered in store image surveys. The first is that the researcher determines the dimensions that will be evaluated by the respondents. The second is that many studies treat store image attributes as being of equal importance, which may not necessarily be the case. In the next section we present some definitions of satisfaction and the scales used to measure this concept.

\section{SATISFACTION}

Retailers must proactively define and measure their customers' satisfaction to stay in business (Hoffman \& Bateson, 2003). According to Sheth, Mittal \& Newman (2001), measuring the degree of satisfaction or dissatisfaction with a product or service based on users' experiences is not a straightforward task.

In evaluating a store, researchers can simply ask: "How satisfied are you with store X?". The difficulty arises in understanding why customers feel a particular way. There are two ways to resolve this difficulty. The first is to ask the customer to classify the store based on its various attributes. The satisfaction or dissatisfaction with these various attributes can be used to explain the customer's general level of satisfaction with the store. However, this approach leads to another question: What causes the satisfaction or dissatisfaction with the individual attributes? The second solution is that satisfaction does not depend on absolute levels of performance of the various attributes, but rather on how the real performance stacks 
up against the customer's expectation. From this standpoint, if the experience with the store meets the expectation before buying, the result is satisfaction. Likewise, if the initial expectation is not met, the result is dissatisfaction. Based on this theory, satisfaction or dissatisfaction arises from whether or not the customer's expectations are confirmed (Sheth, Mitall \& Newman, 2001).

This theory of satisfaction has important implications for modeling expectations (Sheth \& Mittal, 1996). If a company promises too much, it can create expectations about a product or service that are impossible to fulfill, causing customers to be unsatisfied. In contrast, if expectations are very low, customers may not even buy the product or service. Therefore, the correct strategy is to create realistic expectations that are attractive enough to prompt consumers to buy and be satisfied with the resulting experience.

Hunt (1991) and Sheth, Mittal \& Newman (2001) defined satisfaction according to the same theory. For these authors, satisfaction or dissatisfaction always entails a comparison of customers' expectations with their perceptions of the product, service or store. This theory is based on the expectancy disconfirmation model, according to which if a customer's perceptions are fulfilled, he or she is said to be satisfied.

Customer satisfaction results in various benefits for a store. Satisfied customers buy more often and there is less chance of losing them to rivals. A retailer with satisfied customers has a greater chance of rising above competitive pressures, especially related to price (Hoffman \& Bateson, 2003).

Customer satisfaction studies are an important tool to obtain feedback, which can identify problems and opportunities. Another benefit is that such studies convey the message to customers that the store is concerned about their welfare and values their information on how it is operating. The results of customer satisfaction surveys are often used for setting bonuses to sales staff and managers. They are also useful for purposes of comparison against competitors (Hoffman \& Bateson, 2003).

According to Hoffman \& Bateson (2003), customer satisfaction can be measured directly or indirectly. Indirect measurement consists of monitoring sales, profits and complaints, for instance. Direct measurement generally involves customer satisfaction surveys, asking respondents to rank attributes on a scale (such as $0-100$ ) or by a range of "very unsatisfied-very satisfied" responses, or a combination of these. In the first method, the 
survey subjects are asked to assign a number, for example from 0 to 100 , to various attributes to indicate their degree of satisfaction with the various aspects being measured. In the second method the respondents are asked to choose a range of responses on a five-point scale, generally in the following form: very unsatisfied, relatively unsatisfied, neutral, relatively satisfied and very satisfied. Although this second method has more significance for the satisfaction index, it does not have diagnostic power, to indicate specific areas for improvement.

These two methods can be combined to measure customer satisfaction. A scale of 0 to 10 is used to allow customers to express their feelings about the store between two extremes. The combined method uses the quantitative scoring of the "very dissatisfied/very satisfied" method and adds a qualitative analysis, asking the respondents to suggest improvements to any items where the ranking falls short of very satisfied. This method permits the retailer to obtain comparative advantages of quantitative data and also the benefits of qualitative data (Hoffman \& Bateson, 2003)

\section{RELATIONSHIP BETWEEN STORE IMAGE AND CUSTOMER SATISFACTION}

Store image and customer satisfaction are closely connected concepts. Bloemer \& Ruyter (1998) stated that store image acts as a mediator of satisfaction and pointed out that high customer satisfaction will reflect positively on the store's image.

The authors concluded that customer loyalty is directly related to satisfaction, and that satisfaction comes from the various attributes of the store's image. This conclusion leads to two points about store image. The first is that store image indirectly influences loyalty, through satisfaction. The second is that a store's image directly influences its customers' satisfaction level.

Theodoridis \& Chatzipanagiotou (2009) conducted a similar study. Their aim was to discover the relationship between the image attributes and satisfaction of a Greek supermarket. First, based on the theory of image in retailing, the authors performed a factor analysis and detected six factors composing the store's image: service, atmosphere, products, price, merchandise presentation and in-store convenience. Then they performed multiple regression analysis to relate these factors with the questions involved in determining satisfaction.

The results indicated that only four of the six factors had a significant impact on customer satisfaction: service, price, products and in-store convenience. Price and products 
were the key factors to determine customer satisfaction. Therefore, the hypothesis that image attributes have a positive effect on customer satisfaction can be partially accepted, since two of the attributes (merchandise presentation and atmosphere) did not have a significant impact on customer satisfaction. Another result of their study was that store image attributes and satisfaction are strongly related. In other words, Greek shoppers evaluate store image as something important for their level of satisfaction.

\section{METHODOLOGICAL ASPECTS OF FIELD RESEARCH}

The aim of this study is to present the influence of store image on the satisfaction level of the customers of a shoe store, obtained by applying a structured questionnaire to a sample of the store's patrons formulate. It also has a.

The survey presented here can be classified as descriptive (Malhotra, 2001), since the aim is to identify the image customers have of the store and relate this to their satisfaction. We chose a Likert scale to measure store image because it is easy for respondents to understand and also easy to second advantage specifically in relation to the semantic differential scale, because in the latter it is difficult to determine suitable opposing adjectives to construct the questionnaire. Finally, the Stapel scale is confusing and can be hard to apply in many research settings (Malhotra, 2001).

The Likert scale in its original conception is an ordinal scale. In other words, it is a non-metric scale where the variables can be ordered in relation to the respondent's level of agreement with the statements (Hair Jr. et al., 2005). However, there is a good deal of discussion about the best way to measure constructs such as attitudes and images - whether ordinal or interval scales are most suitable. According to Churchill (1991), the prevailing position among marketing researchers concurs with that of many psychologists: attitude scales should be based on intervals, or at least considered as such. Therefore, based on the preponderant position reported by Churchill (1991), we decided to apply metric statistics to treat the Likert scale.

To measure the target store's image, we decided to use a five-point scale, to simplify the process of filling out the questionnaire. Therefore, we formulated some statements and asked the respondents to choose among the following response categories: "totally disagree", "somewhat disagree", "neither agree nor disagree", "somewhat agree" and "totally agree". Some statements were negative and others affirmative, to avoid the so-called "halo effect". 
For the sake of consistency, in the statistical analyses we inverted the signs of the items with negative meanings, so that all items had the same sense. (Malhotra, 2001).

In turn, to measure the "satisfaction" variable, the respondents assigned a score from 0 to 10 , with 0 standing for "not at all satisfied" and 10 corresponding to "totally satisfied". There were five more questions at the end using nominal scales, to describe the respondent's profile (period as a customer, sex, age, schooling level and frequency of shopping at the store). The population was defined considering customers who had purchased something at the store. The store is located in a small city in the state of Minas Gerais and has been in business since 2002. It has about 1700 listed customers, but the actual number is much greater because this list only contains those buying on installment payments.

The questionnaires were applied in printed form to customers who had purchased something. A store employee asked them if they would be willing to fill out a short questionnaire and if so, gave a short explanation to facilitate understanding. To preserve anonymity, the respondents placed the completed questionnaires in a receptacle before leaving the store. Given this data collection procedure, the sample was of the nonprobabilistic convenience type.

\section{RESULTS AND DISCUSSION}

During the study period 123 people filled out the questionnaires. Of the respondents, $62.5 \%$ were between 31 and 50 years old and $84.2 \%$ were women. The majority of the respondents $(67.2 \%)$ had been customers for more than two years and most of them $(62 \%)$ did not have high-school diplomas. Finally, the average customer satisfaction was impressively high, at 9.11 out of 10 , with a small standard deviation, reflecting the fact that the majority of responses were between 8 and 10 .

We applied factor analysis to facilitate the subsequent regression analysis, applied to the set of variables contained in the 20 statements evaluating the store's image, using a Likert scale from 1 to 5 . We used an anti-image correlation matrix for the factor analysis, whereby the diagonal contains the sampling adequacy measures (SAM) for each variable. Two variables presented values below 0.5. According to Hair Jr. et al. (2005), when the SAM value is below 0.5 , that variable should be discarded from the factor analysis because it can interfere in the analysis. Therefore, we excluded these two variables, leaving a set of 18 total variables.

With respect to the critical assumptions necessary to perform factor analysis, we performed the Bartlett and Kaiser-Meyer-Olkin (KMO) tests. The results showed that the data 
were adequate to apply factor analysis. The value of the KMO test was 0.628 , a result that is higher than the minimum acceptable level of 0.5, according to Hair Jr. et al. (2005).

We used principal components analysis with Varimax rotation to extract the data utilized in the factor analysis. The initial criterion for determining the number of factors to be evaluated was those with eigenvalues greater than 1 . Through this criterion we obtained eight factors that together explained $69.07 \%$ of the total variance. Although this variance explanation level was good, the interpretation of the factors was hampered because some factors only had one or two variables. Therefore, we performed another factor analysis with a forced solution based on seven factors to try to improve the results. The total variance explained was $63.49 \%$. Although this was slightly lower than the percentage obtained with eight factors, it was still adequate for being above 60\% (Hair Jr. et al., 2005). Chart 1 shows the factor loadings obtained in the forced solution with seven factors rotated by the Varimax method. Factors with loading values under 0.2 are omitted from the chart to simplify it.

\begin{tabular}{|c|c|c|c|c|c|c|c|}
\hline \multirow[t]{2}{*}{ Variable } & \multicolumn{7}{|c|}{ Components } \\
\hline & 1 & 2 & 3 & 4 & 5 & 6 & 7 \\
\hline $\begin{array}{l}\text { When I go to the store, I find very few buying } \\
\text { options. }\end{array}$ & 0.658 & & & & & & \\
\hline The shoes sold at the store are of poor quality. & 0.654 & & 0.218 & & & 0.343 & \\
\hline $\begin{array}{l}\text { The installment payment options do not meet my } \\
\text { needs. }\end{array}$ & 0.608 & & & 0.365 & -0.367 & & -0.232 \\
\hline $\begin{array}{l}\text { When I shop at the store, I always find the shoes } \\
\text { I'm looking for. }\end{array}$ & 0.465 & 0.431 & 0.248 & & & & 0.244 \\
\hline The shoes are well displayed. & & 0.729 & & & & & \\
\hline The salespeople are friendly. & & 0.570 & & & & 0.202 & \\
\hline The store location is good. & -0.397 & 0.569 & 0.352 & & & 0.251 & \\
\hline $\begin{array}{l}\text { The store renews its stock frequently, to keep up } \\
\text { with the latest style trends. }\end{array}$ & & 0.544 & 0.266 & & & -0.407 & 0.241 \\
\hline The store is well known in the city. & & & 0.756 & & & & \\
\hline The store is a pleasant place to shop. & & & 0.739 & 0.205 & & & -0.241 \\
\hline $\begin{array}{l}\text { The store sells more expensive shoes than its } \\
\text { competitors. }\end{array}$ & & & 0.220 & 0.742 & & & 0.239 \\
\hline The prices are low. & & & & 0.662 & & & \\
\hline I've heard someone badmouth the store. & & & & & 0.790 & & 0.204 \\
\hline The store has a good internal appearance. & 0.347 & 0.292 & & 0.306 & 0.583 & & \\
\hline The store is cramped. & & & -0.202 & 0.472 & 0.523 & 0.251 & \\
\hline The store is disorganized. & & & 0.266 & & & 0.788 & \\
\hline The service is fast. & & 0.237 & -0.302 & 0.412 & & 0.521 & 0.292 \\
\hline The salespeople always clear up may doubts. & & & & & & & 0.826 \\
\hline
\end{tabular}

\section{CHART 2 - ROTATED COMPONENT MATRIX}

Source: Authors 
Another step in interpreting the factors involves testing the reliability of the result obtained. The reliability coefficient used in this study was Cronbach's alpha. According to Hair Jr. et al. (2005), the lower bound for Cronbach's alpha is 0.7 , or 0.6 in exploratory studies. George \& Mallery (2003) provide the following classification according to the alpha value: above 0.9 is excellent; between 0.8 and 0.9 is good; between 0.7 and 0.8 is acceptable; between 0.6 and 0.7 is questionable; between 0.5 and 0.6 is poor; and below 0.5 is unacceptable. According to Streiner (2003), the greater the correlation of the items on a scale, the higher will be Cronbach's alpha. Therefore, the alpha value is strongly affected by the number of items on the scale, according to Cortina (1993) (in this study the number of store image statements). The table below presents the seven factors and their respective values of Cronbach's alpha and explained variance.

Table 1 - Summary of the factor analysis

\begin{tabular}{|c|c|c|c|}
\hline Factors & Variables composing the factor & $\begin{array}{c}\text { Value of } \\
\text { Cronbach's } \alpha\end{array}$ & $\begin{array}{l}\% \text { of the } \\
\text { variance } \\
\text { explained }\end{array}$ \\
\hline Assortment & $\begin{array}{c}\text { "When I go to the store, I find very few buying options", } \\
\text { "The shoes sold at the store are of poor quality", "The } \\
\text { installment payment options do not meet my needs" and } \\
\text { "When I shop at the store, I always find the shoes I'm } \\
\text { looking for" }\end{array}$ & 0.577 & $10.33 \%$ \\
\hline Convenience & $\begin{array}{c}\text { "The shoes are well displayed", "The salespeople are } \\
\text { friendly", "The store location is good" and "The store } \\
\text { renews its stock frequently, to keep up with the latest } \\
\text { style trends" }\end{array}$ & 0.469 & $10.31 \%$ \\
\hline Reputation & $\begin{array}{c}\text { "The store is well known in the city" and "The store is a } \\
\text { pleasant place to shop" }\end{array}$ & 0.554 & $9.68 \%$ \\
\hline Price & $\begin{array}{l}\text { "The store sells more expensive shoes than its } \\
\text { competitors" and "The prices are low" }\end{array}$ & 0.593 & $9.56 \%$ \\
\hline Atmosphere & $\begin{array}{c}\text { "I've heard someone badmouth the store", "The store } \\
\text { has a good internal appearance" and "The store is } \\
\text { cramped " }\end{array}$ & 0.438 & $8.43 \%$ \\
\hline Layout & "The store is disorganized" and "The service is fast" & 0.454 & $8.31 \%$ \\
\hline Service & "The salespeople always clear up may doubts" & - & $6.88 \%$ \\
\hline
\end{tabular}

Source: Authors.

To perform the multiple regression with the seven image factors identified from the factor analysis, it was necessary to calculate new scores for each factor. To do this we combined the variables composing each factor, using the mean score of each as a replacement variable (Hair Jr. et al., 2005), to produce the independent variables for the regression analysis. The dependent variables were the responses to the satisfaction question, on a scale 
from 0 to 10. Table 2 shows the descriptive statistics of the seven image factors obtained in this survey. The service dimension received the highest scores (average of 4.767), indicating that store service is the most important image dimension among customers. The price dimension received the lowest average score.

Table 2 - Descriptive statistics of the image factors

\begin{tabular}{c|c|c|c|c}
\hline & Minimum & Maximum & Mean & Standard Deviation \\
\hline Service & 1.00 & 5 & 4.767 & 0.670 \\
\hline Reputation & 2.33 & 5 & 4.715 & 0.572 \\
\hline Layout & 1.00 & 5 & 4.699 & 0.827 \\
\hline Convenience & 2.00 & 5 & 4.580 & 0.609 \\
\hline Atmosphere & 1.00 & 5 & 4.455 & 0.822 \\
\hline Assortment & 1.75 & 5 & 4.113 & 0.848 \\
\hline Price & 1.00 & 5 & 3.934 & 1.134 \\
\hline
\end{tabular}

Source: Authors.

It is important in regression analysis to check for multicollinearity among the independent variables. We used two measures to identify multicollinearity: the correlation matrix of the independent variables and the tolerance value (Hair Jr. et al., 2005). There was no sign indicating multicollinearity of the variables. Table 3 summarizes the regression model estimated to verify the influence of store image on customer satisfaction.

Table 3 - Summary of the regression model

\begin{tabular}{c|c|c|c|c}
\hline Model & $\mathbf{R}$ & $\mathbf{R}^{\mathbf{2}}$ & Adjusted $\mathbf{R}^{\mathbf{2}}$ & Standard error of the estimate \\
\hline 1 & 0.523 & 0.273 & 0.229 & 0.817 \\
\hline
\end{tabular}

Source: Authors.

In this model with seven independent variables, $\mathrm{R}^{2}$ was equal to 0.273 . This indicates a moderate relation between the variables, with the store image variables explaining $27.3 \%$ of the variation in customer satisfaction with the store (Malhotra, 2001). Other studies have shown that store image has an influence on customer satisfaction (Bloemer \& Ruyter, 1998; Theodoridis \& Chatzipanagiotou, 2009). However, these studies do not mention what values of $\mathrm{R}^{2}$ would lead to a strong influence of store image on satisfaction. Nevertheless, since this is a study in the area of the social sciences, we can conclude there was a moderate dependence relationship between the store image variables and satisfaction. The customers who answered the questionnaire generally held store image to be something important for their satisfaction levels. It must be mentioned that there are factors other than image that also influence customers' satisfaction with a store. Despite this, in this study store image was responsible for nearly $30 \%$ of the variation in satisfaction. The coefficient of correlation (R) of 0.523 indicates there was a positive correlation between satisfaction and store image, i.e., customers 
with a better rating of the store image dimensions tended to be more satisfied. To verify whether the influence of the image dimensions on the dependent variable satisfaction is positive or negative and which image variables most influence satisfaction, we analyzed the regression coefficients of the model. Table 4 presents these coefficients.

Table 4 - Coefficients of the regression model

\begin{tabular}{c|c|c|c|c|c}
\hline & \multicolumn{2}{|c|}{ Nonstandardized coefficients } & $\begin{array}{c}\text { Collinearity } \\
\text { statistic }\end{array}$ & F & Sig. \\
\hline & $\boldsymbol{\beta}$ & Standard error & Tolerance & & 0.000 \\
\hline (Constant) & 4.552 & 0.986 & & 4.617 & 0.005 \\
\hline Service & 0.334 & 0.117 & 0.911 & 2.853 & 0.037 \\
\hline Convenience & 0.269 & 0.127 & 0.908 & 2.113 & 0.056 \\
\hline Assortment & 0.178 & 0.092 & 0.892 & 1.928 & 0.079 \\
\hline Reputation & 0.168 & 0.095 & 0.902 & 1.772 & 0.066 \\
\hline Price & 0.135 & 0.073 & 0.806 & 1.854 & 0.862 \\
\hline Atmosphere & -0.024 & 0.135 & 0.917 & -0.174 & 0.698 \\
\hline Layout & -0.036 & 0.093 & 0.925 & -0.389 & 0 \\
\hline
\end{tabular}

Source: Authors

The nonstandardized regression coefficients showed that the store image variable with the highest $\beta$ is service, (0.334) and the lowest is layout (-0.036). It is important to recall that the dependent variables represent customers' evaluation of the store's image, so the higher the value of these variables, the better the respondents' image of the store. The same is true of the dependent variable: the higher it is, the more satisfied customers are with the store. In light of these facts, the size and sign of the regression coefficients can be interpreted. Since the coefficients of the dimensions assortment, convenience, reputation and service are positive, this means that when the value of one of these variables increases, the level of satisfaction also increases. Therefore, customers' satisfaction with the store is more positive as the values of these variables rise. On the other hand, the coefficients of the dimensions atmosphere and layout are negative but very near zero. If the sample had been probabilistic, these two coefficients would not be considered statistically significant at the $90 \%$ confidence level. Because of this, these two coefficients are considered as being zero and thus as having no influence on satisfaction.

The only dimensions with an impact on satisfaction, then, are assortment, convenience, reputation and price, and all of them are positive.From the coefficients shown in Table 4 , it can be seen that the attributes that most influence satisfaction are service and convenience, followed by assortment, reputation and price. The fact that the service dimension has the most influence on satisfaction and this dimension is also the highest ranked 
is a positive point of the store, because it shows that the factor that most influences customer satisfaction is also the store's strongest point. The results obtained indicate that store image is a multidimensional construct, with each dimension exercising a different influence on satisfaction. A comparison of these results with those of Theodoridis \& Chatzipanagiotou (2009), who also sought to relate image dimensions with satisfaction, reveals some similarities and some differences. One similarity regards the dimensions without any influence on satisfaction. Both studies show the atmosphere dimension as having no significant influence on customers' satisfaction.

A difference involves the influence of price. In both studies it had a positive influence, but in the study by Theodoridis \& Chatzipanagiotou (2009) this relation was much stronger. This might be due to the difference in segments studied. Prices is more important in the supermarket segment than in the footwear segment, because in the former service is minimal since shoppers are generally left to their own devices. Also, most supermarkets do not have their own credit system. Therefore, price has a much greater bearing on customer satisfaction in a supermarket. Another difference is that the product dimension in Theodoridis \& Chatzipanagiotou (2009) was second most important on the degree of satisfaction, while the assortment dimension in our study was in third place. The last difference is in the service dimension. In the Greek supermarket study, while this had a significant impact on satisfaction, it only appeared in fourth place, while in the present study it was the most important element. This difference once again can be explained by the segments. Since in a supermarket there is much less contact between shoppers and staff than in a shoe store, service has less importance in the former case.

\section{FINAL CONSIDERATIONS}

The objective of this study was to discover how the image customers have of a shoe store affects their level of satisfaction, and what image dimensions play the most important roles. The findings indicate that image has an influence of nearly $30 \%$ on customers' satisfaction with the store studied. The image dimensions in this study were assortment, convenience, reputation, price, atmosphere, layout and service. We found that the dimension evaluated the highest by the respondents was service, while the dimension that received the lowest evaluation was price. This can mean that for the store to improve its image among customers, it should lower its prices. According to the respondents, the dimension that most affects their satisfaction is also service. 
This finding shows that for the store studied, service has a great impact on satisfaction. In contrast, two image dimensions have virtually no impact on satisfaction: atmosphere and layout. The order of the other dimensions, from most to least important, was convenience, assortment, reputation and price.

A comparison of these results with the mentioned study of the supermarket segment shows that the main differences are in the influence of price and service: in the supermarket study price had the most influence on satisfaction while service had very little influence.The overall conclusion is that store image plays an important role in determining customer satisfaction, so retailers should pay close attention to this in their marketing efforts. Surveys of store image are important to discover which attributes are most important in determining satisfaction and also which are viewed as the worst by customers, permitting the store to focus its actions on the specific factors that need improvement.

The conclusions here are especially important for the Brazilian footwear retailing segment, where there are few studies, both specifically of image and more generally on marketing. Besides this, the results obtained here can offer elements for discussion in future surveys in this area and encourage more academic research into shoe retailing.

We believe the results will allow retailing professionals and academics to better understand the role of various store image dimensions and the image construct itself on customer satisfaction. We also believe this survey makes a contribution to the study of store image because it focuses on a segment not studied before in Brazil. Some limitations must be mentioned however. One is the target population, which was restricted only to customers of one store. Another was that the non-probabilistic sampling method means the results cannot be generalized to the entire research population.

A suggestion for future study would be to expand the number of stores studied, to obtain a broader sample not associated with only one retailer. Another suggestion is to include other variables in the model that can influence satisfaction. Finally, other studies can be conducted with samples having different characteristics or in other retail segments, to allow comparison with the results here.

\section{REFERENCES}

ASSOCIAÇÃO BRASILEIRA DAS INDÚSTRIAS DE CALÇADOS. Resenha estatística. Novo Hamburgo: 2008. Dísponível em: <http://www.abicalcados.com.br/estatisticas.html $>$. Acesso em: 03 abr. 2009. 
BEARDEN, W. O. Determinant attributes of store patronage: downtown versus outlying shopping areas. Journal of Retailing, v. 53, n. 2, p. 15-22, 1977.

BIRTWISTLE, G.; CLARKE, I.; FREATHY, P. Store image in the UK fashion sector: consumer versus retailer perceptions. The International Review of Retail, Distribution and Consumer Research, v. 9, n. 1, p. 1-16, jan. 1999.

BLACWELL, R. D.; MINIARD, P. W.; ENGEL, J. F. Comportamento do consumidor. Tradução Eduardo Teixeira Ayrosa. 9. ed. São Paulo: Thomson, 2005.

BLOEMER, J.; RUYTER, K. On the relationship between store image, store satisfaction and store loyalty. European Journal of Marketing, West Yorkshire: MCB Publications, v. 32, Iss. 5/6, p. 499-513, 1998.

BLOEMER, J.; SCHRODER, G. O. Store satisfaction and store loyalty explained by customer and store related factors. Journal of Consumer Satisfaction, Dissatisfaction and Complaining Behavior, v. 15, p. 68-80, 2002.

CHURCHILL, G. A. Marketing research: methodological foundations. Fort Worth: The Dryden Press, 1991.

CORTINA, J. M. What is coefficient alpha?: an examination of theory and applications. Journal of Applied Psycology, v. 78, n.1, 98-104, 1993.

DOYLE, P; FENWICK, I. Shopping habits in grocery chains. Journal of Retailing, v. 50, p. 39-52, 1974.

GEORGE, D.; MALLERY, P. SPSS for Windows step by step: a simple guide and reference. 4. ed. Boston: Allyn \& Bacon, 2003.

GHOSH, A. Retail management. New York: Dryden Press, 1990.

HAIR JÚNIOR, J. F. et al. Análise multivariada de dados. Tradução Adonai Schlup Sant'Anna e Anselmo Chaves Neto. 5. ed. Porto Alegre: Bookman, 2005.

HAWKINS, D. I.; MOTHERSBAUGH, D. L.; BEST, T. J. Comportamento do consumidor: construindo a estratégia de marketing. Tradução Cláudia Mello Belhassof. 10. ed. Rio de Janeiro: Elsevier, 2007.

HOFFMAN, K. D.; BATESON, J.E.G. Princípios de Marketing de serviços: conceitos, estratégias e casos. Tradução Brasil Ramos Fernandes. 2. ed. São Paulo: Pioneira Thomson Learning, 2003.

HUNT, K. Consumer satisfaction, dissatisfaction and complaining behavior. Jounal of Social Issues. v. 47, n. 1, p. 109-110, 1991

IBGE. INSTITUTO BRASILEIRO DE GEOGRAFIA E ESTATÍSTICA. Pesquisa Anual de Comércio. Volume 17. Rio de Janeiro: 2005. 143 p. 
Pesquisa Anual de Comércio. Volume 18. Rio de Janeiro: 2006. 153 p.

JAMES, D. L.; DURAND R. M.; DREVES, R. A. The Use of a multi-attribute attitude model in a store image study. Journal of Retailing, v. 32, n. 2, p. 23-32, 1976.

KEAVENEY, S. M. Conceptualization and operationalization of retail store image: a case of rival middle-level theories. Journal of the Academy Marketing Science, p. 165-175, 1992.

KUNKEL, J. H.; BERRY, L. L. A Behavioral conception of retail image. Journal of Marketing, New York: v. 32, n. 4, p. 29-38, 1968.

LINDQUIST, J. D. Meaning of image: survey of empirical and hypothetical evidence. Journal of Retailing, p. 29-38, 1974.

MALHOTRA, N. K. Pesquisa de Marketing: uma orientação aplicada. Tradução Nivaldo Montingelli Jr. e Alfredo Alves de Farias. 3. ed. Porto Alegre: Bookman, 2001.

MARTINEAU, P. The Personality of the retail store. Harvard Business Review, v. 36, p. 47-55, Jan./Feb. 1958.

MCGOLDRICK, P. J. Retail marketing. London: McGraw-Hill, 1990.

MENEZES, D.; ELBERT, N. F. Alternative semantic scaling formats for measuring store image: an evaluation. Journal of Marketing Research, v. 16, p. 80-87, fev. 1979.

PARENTE, J. Varejo no Brasil: gestão e estratégia. São Paulo: Atlas, 2000.

REARDON, J.; MILLER, C. E.; COE, B. Applied scale development: measurement of stores image. Journal of Applied Business Research, v. 11, n. 4, p. 85-93, 1995.

SANTOS F.; DIAS, A. M. Varejo de calçados evolui e mostra sua força. Couromoda, São Paulo, 21 ago. 2008. Disponível em:

$<$ http://www.couromoda.com/noticias/setor_gerais/Gnoticia_2569.html >. Acesso em: 10 maio 2009.

SHETH, J. N.; MITTAL, B.; NEWMAN, B. I. Comportamento do cliente: indo além do comportamento do consumidor. São Paulo: Atlas, 2001.

SHETH, J.; MITTAL, B. A Framework for managing customer expectations. Journal of Marketing- Focused Management, v. 1, p. 137-158, 1996.

STREINER, D. L. Starting at the beginning: an introduction to coefficient alpha and internal consistency. Journal of Personality Assessment, v. 80, p. 99-103, 2003.

THEODORIDIS, P. K.; CHATZIPANAGIOTOU, K. C. Store image attributes and customer satisfaction across different customer profiles within the supermarket sector in Greece.

European Journal of Marketing, v. 43, n. 5/6, p. 708-734, 2009. 